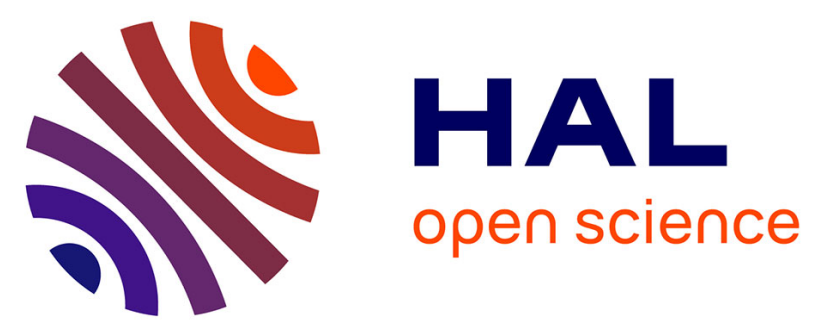

\title{
Development of a Thermal Energy Storage Pressed Plate Ceramic Based on Municipal Waste Incinerator Bottom Ash and Waste Clay
} N. Lopez Ferber, Doan Pham Minh, Q. Falcoz, Anca Meffre, N. Tessier-Doyen, Ange Nzihou, V. Goetz

\section{To cite this version:}

N. Lopez Ferber, Doan Pham Minh, Q. Falcoz, Anca Meffre, N. Tessier-Doyen, et al.. Development of a Thermal Energy Storage Pressed Plate Ceramic Based on Municipal Waste Incinerator Bottom Ash and Waste Clay. Waste and Biomass Valorization, 2020, 11 (2), pp.689-699. 10.1007/s12649019-00629-6 . hal-02064155

\section{HAL Id: hal-02064155 https://imt-mines-albi.hal.science/hal-02064155}

Submitted on 11 Mar 2019

HAL is a multi-disciplinary open access archive for the deposit and dissemination of scientific research documents, whether they are published or not. The documents may come from teaching and research institutions in France or abroad, or from public or private research centers.
L'archive ouverte pluridisciplinaire HAL, est destinée au dépôt et à la diffusion de documents scientifiques de niveau recherche, publiés ou non, émanant des établissements d'enseignement et de recherche français ou étrangers, des laboratoires publics ou privés. 


\title{
Development of a Thermal Energy Storage Pressed Plate Ceramic Based on Municipal Waste Incinerator Bottom Ash and Waste Clay
}

\author{
N. Lopez Ferber ${ }^{1,2,3} \cdot$ D. Pham Minh $^{2} \cdot$ Q. Falcoz ${ }^{1} \cdot$ A. Meffre ${ }^{3} \cdot$ N. Tessier-Doyen ${ }^{4} \cdot$ A. Nzihou ${ }^{2} \cdot$ V. Goetz $^{1}$
}

\begin{abstract}
Pressed plates ceramics made of gross-milled bottom ashes and waste clay, were made using technologies available in the building bricks and tiles industry, to ease production upscaling at low-cost. These sintered ceramics are intended for use as a high-temperature thermal energy storage material. They represent an alternative to the waste-based petrurgic ceramics previously developed for this application. Post-treated incinerator bottom ashes from a commercial incinerator were collected, characterized and processed to form ceramic materials, using clay as a binder. Ashes were milled, dried, and mixed with various amounts of an illitic clay (produced as washing mud by a quartz quarry in proportions from 20 to $70 \%$ dry weight) prior to uniaxial pressing $(12 \times 5 \times 1 \mathrm{~cm}$ slabs $)$ and firing at various temperatures, ranging from 1050 to $1125{ }^{\circ} \mathrm{C}$. The sintered samples have been characterized in terms of volumic mass, mechanical strength, thermal capacity and thermal conductivity. Their mineral structure has also been studied. The resulting sintered ceramics exhibit relatively high mechanical resistance and low thermal conductivity, along with moderate volumic mass. These properties allow envisioning the use as filler material for thermocline thermal storage systems (structured beds), and could be interesting for further work regarding applications in the construction field (bricks, tiles, pavements...).
\end{abstract}

Keywords Thermal energy storage material $\cdot$ Waste-based ceramic $\cdot$ Sintering $\cdot$ Municipal waste incinerator bottom ashes

\section{Statement of Novelty}

The present work is specifically devoted to the development of easy-to-produce ceramics, which could be produced at large industrial scale. For this purpose, the technologies currently used in the materials construction industry have been adapted to transform municipal waste incinerator bottom ashes and waste clay as starting materials to ceramics for

N. Lopez Ferber

n.lopezferber@gmail.com

1 Laboratoire PROMES-CNRS UPR-8521, Université Perpignan Via Domitia, Rambla de la Thermodynamique, Tecnosud, 66100 Perpignan, France

2 Université de Toulouse, IMT Mines Albi, UMR CNRS 5302, Centre RAPSODEE, Campus Jarlard, 81013 Albi Cedex 09, France

3 SAS Eco-Tech Ceram, Espace Entreprises Méditerranée, Rue Edouard Belin, 66600 Rivesaltes, France

4 Science des Procédés Céramiques et de Traitements de Surface, UMR CNRS 7315, Université de Limoges, 12 Rue Atlantis, 87068 Limoges Cedex, France thermal energy storage (TES). This work contributes to the establishment of specifications for the industrial production feasibility of MWIBA ceramics for thermocline heat storage.

\section{Introduction}

Municipal waste incineration is a common technique for household waste (usually high carbon content) treatment. It consists in the combustion of this waste at high temperature (900-1200 $\left.{ }^{\circ} \mathrm{C}\right)$, therefore reducing their volume by up to $90 \%$, decreasing land use compared to direct household wastes landfilling [1, 2]. Most incinerators recover the heat generated to produce industrial steam or electricity. Considered as renewable energy, it represents around $1.7 \mathrm{TWh}_{\mathrm{e}}$ in 2015 in France (comparable to biogas, or solid biomass) [3].

The main solid byproduct of incineration is Municipal Waste Incineration Bottom Ash (MWIBA), representing around $25 \%$ of the total input weight, the others being fly ash, air pollution control residues and dusts [4]. MWIBA is a complex material, with composition varying in time and space, as revealed by the literature (Table 1 ). 
Table 1 Composition of several MWIBA samples studied in the literature

\begin{tabular}{|c|c|c|c|c|c|c|c|c|}
\hline Reference & Vu et al. [5] & $\begin{array}{l}\text { Bethanis et al. } \\
\text { [6] }\end{array}$ & $\begin{array}{l}\text { Barbieri } \\
\text { et al. [7] }\end{array}$ & $\begin{array}{l}\text { Schabbach } \\
\text { et al. [8] }\end{array}$ & Aloisi et al. [9] & $\begin{array}{l}\text { Appendino } \\
\text { et al. [10] }\end{array}$ & $\begin{array}{l}\text { Bourtsalas } \\
\text { et al. } \\
\text { [11] }\end{array}$ & $\begin{array}{l}\text { Barbieri et al. } \\
\text { [12] }\end{array}$ \\
\hline Analysis & ICP AES & ICP AES & XRF & ICP & $\mathrm{XRF}$ & AAS & XRD & ICP \\
\hline \multicolumn{9}{|c|}{ Compound (\% dry weight) } \\
\hline $\mathrm{SiO}_{2}$ & 31.1 & $40.1-42.1$ & 46.7 & $30.3-35.1$ & 40.9 & $42.5-40.9$ & 30.4 & 45.1 \\
\hline $\mathrm{CaO}$ & 10.0 & $18.4-20.0$ & 26.3 & $23.1-26.1$ & 12.2 & $16.4-12.2$ & 26.8 & 18.8 \\
\hline $\mathrm{Al}_{2} \mathrm{O}_{3}$ & 2.57 & $9.92-14.2$ & 6.86 & $13.0-13.6$ & 13.6 & $17.6-13.6$ & 11.5 & 9.73 \\
\hline $\mathrm{Na}_{2} \mathrm{O}$ & 2.10 & $2.60-2.75$ & 4.62 & $1.94-2.44$ & 10.9 & $12.9-10.9$ & 3.32 & 4.64 \\
\hline $\mathrm{MgO}$ & 0.28 & $1.79-1.90$ & 2.22 & $2.83-3.73$ & 3.1 & $2.3-3.1$ & 2.64 & 2.20 \\
\hline $\mathrm{Fe}_{2} \mathrm{O}_{3}$ & 4.36 & $6.20-6.60$ & 4.69 & $10.0-11.5$ & 5.7 & $5.7-5.7$ & 13.1 & 3.84 \\
\hline $\mathrm{TiO}_{2}$ & 0.83 & $1.00-1.14$ & 0.77 & $1.07-1.71$ & 1.2 & $2.5-1.2$ & 1.39 & 0.93 \\
\hline $\mathrm{P}_{2} \mathrm{O}_{5}$ & 2.07 & $1.34-1.44$ & - & $1.96-1.90$ & - & - & 2.18 & - \\
\hline $\mathrm{SO}_{3}$ & 0.60 & - & 2.18 & - & - & - & 3.05 & - \\
\hline $\mathrm{K}_{2} \mathrm{O}$ & 0.86 & $0.86-0.92$ & 0.89 & $0.94-1.45$ & 1.8 & $1.8-1.8$ & 1.33 & 1.29 \\
\hline $\mathrm{CrO} x$ & 0.90 & - & - & - & - & - & - & - \\
\hline $\mathrm{MnO}$ & - & 0.08 & - & $0.18-0.17$ & - & $0.1-0.1$ & 0.31 & - \\
\hline $\begin{array}{l}\text { LOI (\% dry } \\
\text { wt) }\end{array}$ & 5.21 & - & 11 & - & - & - & - & - \\
\hline
\end{tabular}

MWIBA is typically classified as "non-dangerous waste" and is often landfilled (most of the $12 \mathrm{Mt}$ produced annually in Europe is landfilled [1, 2]). Other countries extensively use it although some countries extensively use it as a filler for road sub-base construction. For example, around 80\% of the $3 \mathrm{Mt}$ of bottom ashes generated yearly in France are used as road sub-base filler [2] after several treatment steps involving milling, sieving, ferrous metals removal (magnetic separation) and non-ferrous metals removal (Eddy currents), and ageing (stabilization of leaching properties through calcium oxide carbonation) [13].

Being mostly a mixture of mineral compounds, namely alumina, hematite, silica and alkali oxides in the form of a heterogeneous gravel, MWIBA can be compatible with ceramic materials production $[6,14]$. It can represent a new valorization path providing new feedstock for ceramic industry and saving resources and environmental impacts related to clay and sand extraction. An interesting application calls for high temperature storage systems, using ceramics as sensible thermal storage material in thermocline packed bed or structured bed systems $[15,16]$. Some authors worked on such waste-based ceramics, using molten asbestos containing wastes [17], metallurgical slags [18] or coal fly ash [19], mostly using the petrurgic method implying casting and controlled cooling from molten state, a technique that is not considered as easily transferable to industry and massproduction. Sintering alumino-silicate industrial byproducts appears to be preferable, due to the higher production capabilities of the sintering production pathway [20].

Research projects have been carried out regarding the sintering behavior of MWIBA, but being focused on the sintering or the crystallization behavior of materials containing variable proportions of MWIBA rather than industrial production considerations; the processes and materials they proposed might not be suited for mass-production at reasonable cost (micronic wet-milling [6], casting at molten state or sinter-crystallization from a glass [8], valuable additives like high-grade kaolin [21] and so on).

In this work, we have chosen another perspective aiming to develop a $100 \%$ waste-based ceramic, using production protocols as simple and widely available as possible. The strategy chosen focuses on the simplicity of the production process, because the amount of materials required for sensible heat storage technology could be important, in both the sectors of industrial energetic efficiency and concentrated solar power techniques [22], implying that the developed material should be compatible with mass-production at low cost. This process is based on the uniaxial compression shaping technique, used for example in the tile industry (and in most of the literature regarding MWIBA use as ceramic production feedstock). The ceramics obtained should exhibit properties suitable for sensible heat thermal storage up to $1000{ }^{\circ} \mathrm{C}$, under air, in a thermocline thermal storage system. Hence, the desired properties of the resulting material are as follows:

- Maximal volumetric thermal capacity ( $\rho$ x Cp), implying maximizing densification during sintering. This is especially important for thermal storage applications, since it would increase thermal storage capacity per unit volume.

- High thermal conductivity, that is beneficial for storage behavior in thermocline air/ceramic storage systems, 
ensuring that the Biot number is significantly lower than 1 (heat transfer between the air and the solid does not generate a significant inta-particle thermal gradient). This could also be achieved by decreasing the size of the particle, at the cost of increased pressure drop.

- Satisfying mechanical strength, measured as compressive strength (>20 MPa). A high compressive strength for a thermal storage material will allow increasing the weight of the bed without damaging the pieces.

- Thermal stability over a large range of temperatures that can be encountered in thermal energy storage (up to 800-1000 ${ }^{\circ} \mathrm{C}$ ), under air

- Satisfying thermomechanical behavior, measured as the Coefficient of Thermal Expansion (CTE). This CTE should be as low as possible, or at least present predictable variations with temperature, to avoid increasing mechanical stress during use.

This paper will mostly focus on the influence of the clay to bottom ash ratio in the formulation and firing temperature on the resulting properties of the sintered samples.

\section{Materials and Methods}

\section{Materials Processing}

\section{Sampling}

$450 \mathrm{~kg}$ of an aged MWIBA have been collected in the maturation platform of a commercial incinerator in southern France using coning and quartering method as defined by the UIPAC [23], after post-treatment process (magnetic removal of ferrous and non-ferrous metals, ageing). The bottom ashes complied with the requirements for homologation as "MWIBA gravel 0-40 mm" as defined in the Setra guide for MWIBA management [13]. Like most MWIBA, it consists in a mixture of ashes, sand, glassy material, metallic and ceramic fragments and residual unburnt organic compounds [24].

\section{Milling}

The particle size distribution (PSD) of as-collected MWIBA was not compatible with shaping and firing protocols, so the
MWIBA had to be milled. The goal being to assess the feasibility of MWIBA ceramics production in building bricks and tile industry, we disregarded extensive wet milling techniques. These techniques, although relevant to produce thin and homogeneous powders, seemed too complicated and not easily transferable to industrial settings, so an easier method has been favored. MWIBA has been dried at $105^{\circ} \mathrm{C}$ for one day, before being milled with a tungsten jaw mill. MWIBA has been milled with three passes inside the jaw mill, the jaw being enclosed between each pass, from a $10 \mathrm{~mm}$ gap to a $1 \mathrm{~mm}$ gap. The powder obtained has then be sieved at $500 \mu \mathrm{m}$ and the passing fraction has then been used for the trials. Milling several hundred grams with this technique requires approximately $45 \mathrm{~s}$, and can be up-scaled reasonably easily due to the great availability of jaw mills in the mineral industries and the fact that these milling devices easily allow continuous production.

\section{Shaping}

Shaping the green bodies before firing being an important step for any applications, adding a binding agent to the MWIBA was considered, in order to give the mixture high enough plasticity to undergo shaping protocols. Thus, a wasted clay was used as binder. This clay is a by-product of a quartz producing company located in southern France, with a generation rate of $100 \mathrm{t} / \mathrm{day}$. It is a fine powder $\left(\mathrm{d}_{50}=16 \mu \mathrm{m}\right)$ of an illitic clay, obtained by flocculation/ decantation of a washing mud. For these trials, we used a hydraulic press, to produce $12 \times 5 \times 1 \mathrm{~cm}$ slabs, after adding water to the powders in a rotary plate device (granulation). The added clay represents $20,30,40$ or $70 \%$ of the formulation dry weight.

\section{Firing}

After being dried at $105{ }^{\circ} \mathrm{C}$ for $12 \mathrm{~h}$, green bodies have been fired in electrical furnaces, with a heating rate of $5^{\circ} \mathrm{C} /$ min from room temperature to $500{ }^{\circ} \mathrm{C}$, then $2{ }^{\circ} \mathrm{C} / \mathrm{min}$ from $500{ }^{\circ} \mathrm{C}$ to the maximum temperature, with isothermal firing duration of $2 \mathrm{~h}$. The furnaces are not equipped with an active cooling system, implying cooling durations of about $10 \mathrm{~h}$. The different stages of the process are illustrated by the Fig. 1.
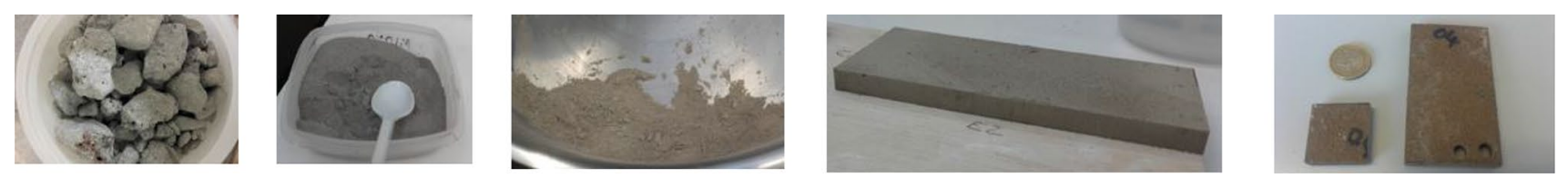

Fig. 1 Process steps. From left to right: raw MWIBA, milled MWIBA, granulated powder mix, green body, fired sample 


\section{Raw Material Characterization}

Chemical composition of the raw materials has been characterized by ICP-AES. Samples have been milled and sieved at $40 \mu \mathrm{m}$. The clay and the MWIBA have been dissolved into a mix of nitric and fluorhydric acid into a micro-wave oven (Anton Paar) under heat. The samples have been heated up to $240{ }^{\circ} \mathrm{C}$ and 60 bars in ten minutes, with 40 min dwell time. After total dissolution, the samples have been characterized using a Perkin-Elmer Optima 8300 ICP device.

PSD of the powders have been measured using a Malvern Mastersizer 3000 granulometer, on carefully dried powders, for a particle size range of $0-1000 \mu \mathrm{m}$.

Loss On Ignition has been measured for the raw powders by comparing the mass of a sample, before and after being heated up to $1000{ }^{\circ} \mathrm{C}$ for $2 \mathrm{~h}$. This characteristic of the powders also had been confirmed with TG-DSC (Labsys Evo from Setaram, with $3 \mathrm{~L} / \mathrm{h}$ air, and a heating rate of $5^{\circ} \mathrm{C} / \mathrm{min}$ from room temperature to $1100{ }^{\circ} \mathrm{C}$ ).

The mineral phases present in the raw materials have been identified with X-Ray Diffraction, using a Philips PANalytical X'pert Pro MPD device (copper emitter, $\mathrm{K}_{\alpha}=1543 \AA$ ), from $2 \theta=10^{\circ}$ to $2 \theta=80^{\circ}$.

\section{Characterization of the Sintered Samples}

The goal being to assess the potential of these ceramics for thermal storage at high temperature, the main properties investigated are as follows:

- Volumic mass, expressed in $\mathrm{kg} / \mathrm{m}^{3}$ or in relative density, has been measured with the Archimede method [25], comparing dry and immersed sample apparent weight.

- Thermal capacity, expressed in $\mathrm{J} /(\mathrm{g} . \mathrm{K})$, has been measured by a modular DSC (Q200 from TA), with a $50 \mathrm{ml} /$ min nitrogen flow, at room temperature and $390{ }^{\circ} \mathrm{C}$, $390{ }^{\circ} \mathrm{C}$ being close to the average temperature of use.

- Thermal diffusivity has been measured with a Laser Flash Analysis device from Netzsch (LFA 457) from room temperature to $1000{ }^{\circ} \mathrm{C}$, with a heating ramp of $20 \%$ min. The knowledge of the variations of specific heat with temperature allowed calculating the thermal conductivity of these samples.

- Thermal stability in the temperature range of $0-1000{ }^{\circ} \mathrm{C}$ is of highest importance. The behavior of the sintered samples under thermal cycling has been investigated with DTA and TMA (Setsys device from Setaram). The coefficient of thermal expansion should also been as low as possible, or at least predictable so to avoid generating strains inside a bed of these materials.

- Compressive strength of the ceramics will set the limit to the system's size. Therefore, high compressive strength can be beneficial to this material. It has been measured by submitting samples to an uniaxial force, using a hydraulic press and increasing the load until sample's rupture, on small cylindrical samples.

- The mineral phases present in the sintered samples have been identified with X-Ray Diffraction, using a Philips PANalytical X'pert Pro MPD device (copper emitter, $\mathrm{K}_{\alpha}$ $=1543 \AA$ ), from $2 \theta=10^{\circ}$ to $2 \theta=80^{\circ}$.

\section{Results and Discussion}

\section{Raw material Characterization}

\section{Composition and Particle Size Distribution}

Both the clay and MWIBA are mostly composed of silica. The clay has higher proportion of alumina and potassium oxides, whereas the MWIBA contains more sodium oxides (Table 2). These last oxides are known for their relevance as fluxing agents, and so might facilitate sintering.

The composition is on part with other MWIBA studied in the scientific literature, although this MWIBA in particular is richer in silicon oxide than most of the samples. Its "lower than usual" content in alumina could be explained by differences in waste-sorting policies.

The clay was not milled, and exhibits a Gaussian-like particle size distribution, centered on its $\mathrm{d}_{50}$ of $16 \mu \mathrm{m}$. The milled MWIBA exhibits a completely different reparation of particle size, with an over-representation of coarse particles $(>100 \mu \mathrm{m})$, mixed with smaller particles. The $\mathrm{d}_{50}$ of the milled MWIBA is $166 \mu \mathrm{m}$, superior of that's of the clay by an order of magnitude (Fig. 2).

This situation, where one of the powder is much coarser and with a sharper distribution and the other one is smaller with a broader PSD is favorable to maximal mixture quality and compacity of the green bodies, the smaller particles being able to fill the porosity between the coarser ones. A difference of particle size of around 1:10 is usually described

Table 2 Chemical composition of clay and MWIBA (ICP-AES)

\begin{tabular}{lll}
\hline Compound (\%wt) & Clay & MWIBA \\
\hline $\mathrm{Al}_{2} \mathrm{O}_{3}$ & 27.1 & 6.2 \\
$\mathrm{SiO}_{2}$ & 53.7 & 58.7 \\
$\mathrm{CaO}$ & 2.3 & 5.3 \\
$\mathrm{Fe}_{2} \mathrm{O}_{3}$ & 5.9 & 6.0 \\
$\mathrm{~K}_{2} \mathrm{O}$ & 5.2 & 1.8 \\
$\mathrm{MgO}$ & - & 2.1 \\
$\mathrm{Na}_{2} \mathrm{O}$ & 0.8 & 7.7 \\
$\mathrm{SO}_{x}$ & - & 1.0 \\
$\mathrm{LOI}\left(100{ }^{\circ} \mathrm{C}\right)(\%$ dry wt) & 4.9 & 5.2 \\
$d_{50}(\mu \mathrm{m})$ & 16 & 166 (milled) \\
\hline
\end{tabular}



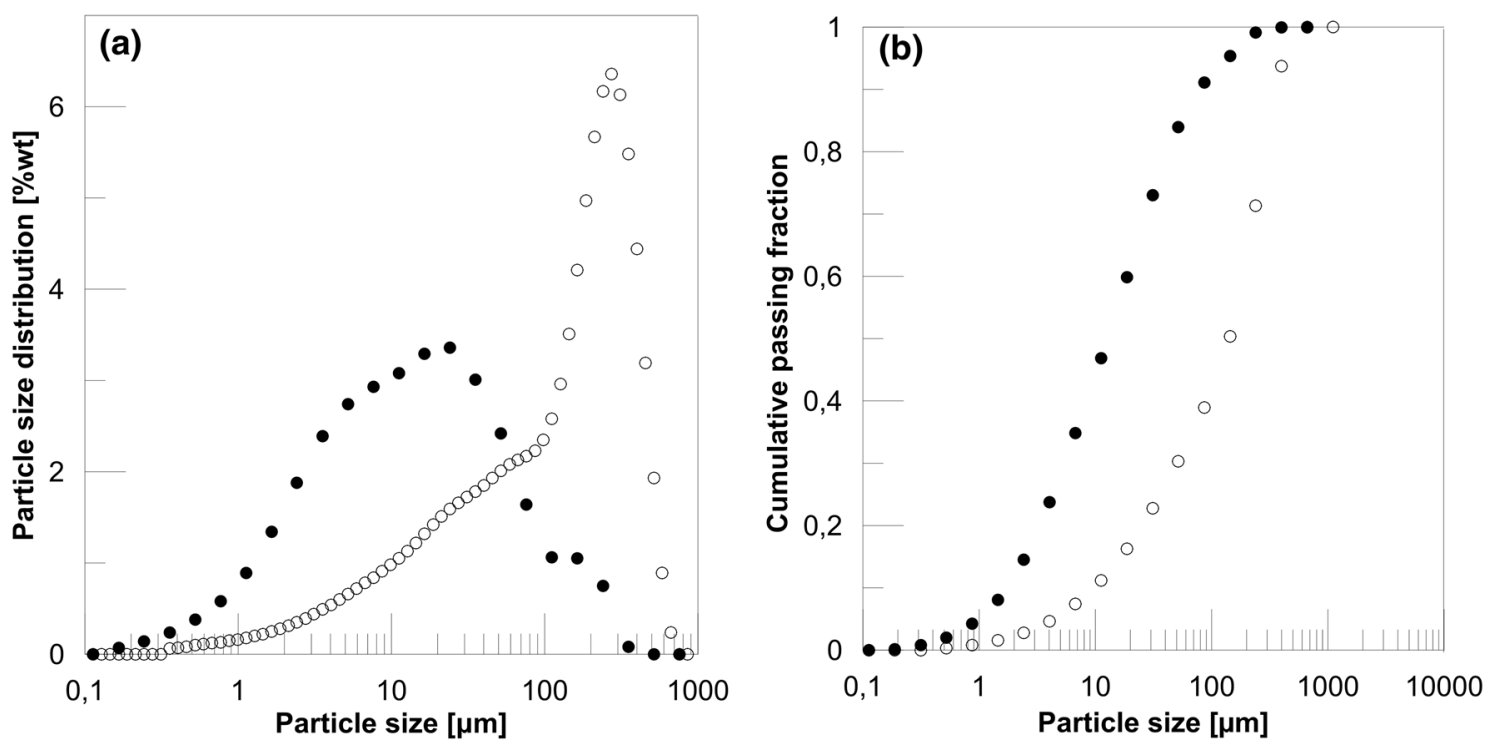

Fig. 2 a Particle size distribution of milled MWIBA (open circle) and clay (filled circle), b cumulative passing fractions of milled MWIBA (open circle) and clay (filled circle)

as relevant for increasing green bodies compacity [26]. The two powders comply with this requirement (Fig. 2), increasing the maximal compacity and homogeneity achievable for the green bodies.

\section{Raw Materials Mineralogy}

Both clay and MWIBA powders have been characterized in terms of mineral composition. The clay exhibits typical illitic clay phases, such as illite and kaolinite, associated with quartz and K-feldspath, (presumably microcline). The MWIBA powder exhibits typical quartz and calcite phases, associated with wollastonite and pyrite (Fig. 3). Pyrite is not usually reported in the literature as being present in bottom ashes, the iron being mostly present as oxide (hematite).

\section{Raw Materials Thermal Behavior}

MWIBA has been milled in a tungsten carbide ring mill and sieved at $50 \mu \mathrm{m}$ to obtain a fine powder suitable for DSC-TG
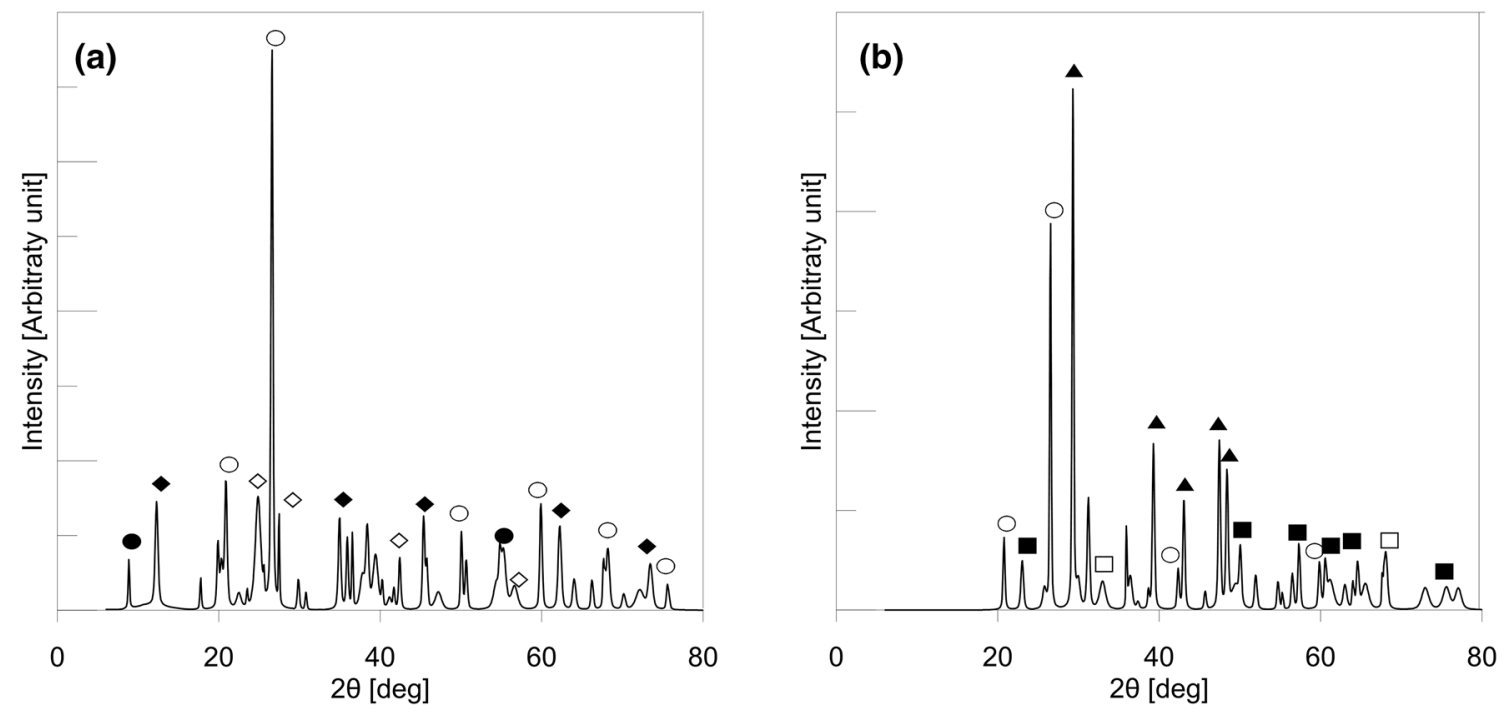

Fig. 3 a XRD diffractogram of raw clay. (filled circle) Illite, (open circle) Quartz, (filled diamond) Kaolinite, (open diamond) K-Feldspath, b XRD diffractogram of raw MWIBA. (open circle) Quartz, (filled triangle) Calcite, (filled square) Wollastonite, (open square) Pyrite 


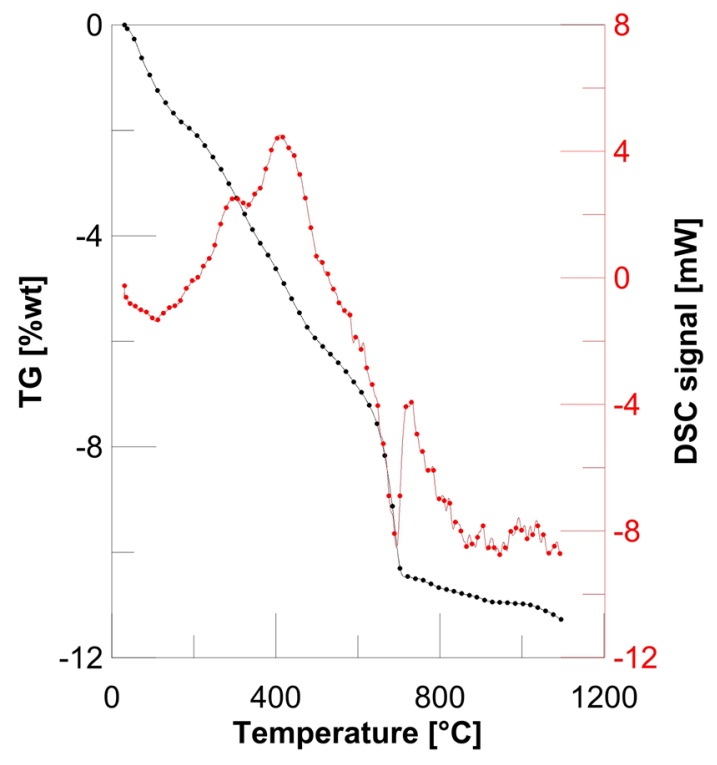

Fig. 4 Thermal behaviour (red) and weight loss (black) up of MWIBA from room temperature to $1100{ }^{\circ} \mathrm{C}$. (Color figure online)

analysis. This sample exhibits a thermal behavior similar to those studied in literature (Fig. 4), namely:

- An endothermic phase between room temperature and around $250{ }^{\circ} \mathrm{C}$, associated with mass loss, which is most often attributed to the vaporization of residual, bound and hydration water.

- An exothermic phase between 300 and $500{ }^{\circ} \mathrm{C}$, associated with mass loss. These peaks are presumably due to the combustion of unburnt organic matter and the release of occluded gases [6].

- A sharp endothermic peak around $700{ }^{\circ} \mathrm{C}$, associated with a sharp weight loss. This is typically associated with calcite decarbonation $\left(\mathrm{CaCO}_{3} \rightarrow \mathrm{CaO}+\mathrm{CO}_{2}\right)$. The usual temperature for calcite decarbonation is around $900{ }^{\circ} \mathrm{C}$, but this phenomenon appears to occur at lower temperature when calcite is found in MWIBA [14, 27, 28]

- Above $1000{ }^{\circ} \mathrm{C}$, the thermal behavior is more difficult to interpret, although partial melting can be observed, and sintering and crystallization phenomena occurs. At high temperature, some weight losses can be attributed to alkali metal sulfates dissociation [6].

The weight loss is higher than noticed during sintering tests, which is presumably due to concentration of volatile residual organic matter into the small-sized particles.

The clay exhibits very common thermal behaviour, with an endothermic peak around $100-150{ }^{\circ} \mathrm{C}$ associated with bounded water removal, followed by a sharp weight loss between 450 and $600{ }^{\circ} \mathrm{C}$ associated to kaolinite deshydroxylation and a $980{ }^{\circ} \mathrm{C}$ exothermic peak related to structural transformation of illite to mullite. This clay starts vitrifying at $1250{ }^{\circ} \mathrm{C}$, a temperature where it reaches its maximum shrinkage (7\%) (Information provided by supplier).

\section{Sintered Samples Properties}

Sixteen batches have been fired by combining four temperatures $\left(1050,1075,1100\right.$ and $\left.1125^{\circ} \mathrm{C}\right)$, with four clay contents $(20 \%, 30 \%, 40 \%$ and $70 \%$ dry weight), to investigate the influence of firing temperature and clay content on fired samples properties. From there, they will be named as follows: XXXX-YY with XXXX the firing temperature $\left[{ }^{\circ} \mathrm{C}\right]$ and YY the clay content [\% dry weight].

\section{Volumic Mass and Loss on Ignition}

The volumic mass of fired samples has been measured with Archimede's method. The samples fired at 1050 and $1075^{\circ} \mathrm{C}$ showed poor cohesion; indicating insufficient grain-bounding during firing. They also exhibited the lowest volumic mass. The samples fired at 1100 and $1125{ }^{\circ} \mathrm{C}$ are much more cohesive (which will be reflected by their compressive strength), and presented higher volumic mass (Table 3), thus have been selected for further characterizations. However, their losses on ignition are also superior, especially for the MWIBA-rich formulations, reaching up to $14 \%$ for the 1125-20 sample, which also exhibited significant closed porosity (Fig. 5). This value is unusually high, and could be related not only to combustion/pyrolysis/dissociation of certain compounds, but also to losses of material (dusts) during firing. This sample also exhibited traces of partial melting.

Table 3 Fired density and LOI of the sintered samples

\begin{tabular}{lll}
\hline Sample & Relative Density $\left(\mathrm{g} / \mathrm{cm}^{3}\right)$ & $\begin{array}{l}\text { LOI }(\% \text { dry } \\
\text { weight })(\%)\end{array}$ \\
\hline $1050-20$ & 1.56 & -2 \\
$1050-30$ & 1.69 & -3 \\
$1050-40$ & 1.65 & -3 \\
$1050-70$ & 1.77 & -3 \\
$1075-20$ & 1.65 & -3 \\
$1075-30$ & 1.74 & -4 \\
$1075-40$ & 1.58 & -5 \\
$1075-70$ & 1.83 & -4 \\
$1100-20$ & 1.72 & -5 \\
$1100-30$ & 1.73 & -2 \\
$1100-40$ & 1.60 & -3 \\
$1100-70$ & 1.83 & -3 \\
$1125-20$ & 2.14 & -14 \\
$1125-30$ & 2.02 & -3 \\
$1125-40$ & 1.80 & -6 \\
$1125-70$ & 1.82 & -4 \\
\hline
\end{tabular}


Fig. 5 Sintered plates samples (40 and 20\% wt clay on the left and right respectively) fired at $1125^{\circ} \mathrm{C}$. The closed porosity of the 1125-20 sample is obvious
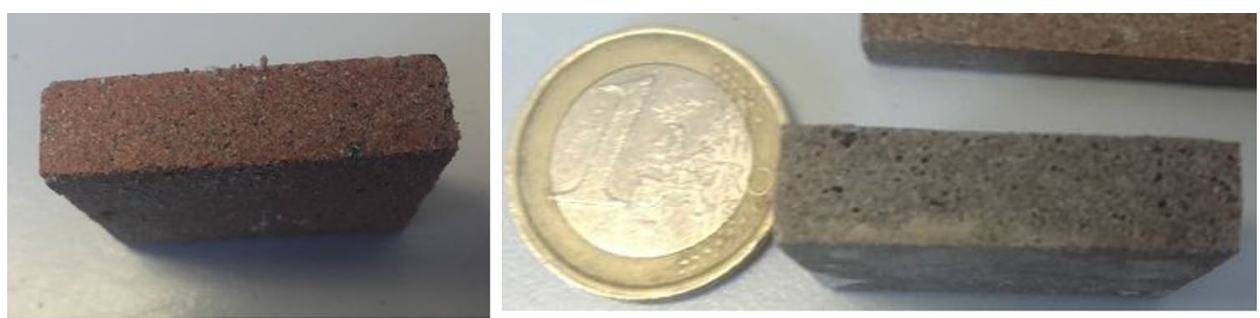

The samples exhibiting the highest densities had tendencies to creep, but the dimensional changes are still reasonable. Shrinkage was not considered as crucial as other properties, and was not properly investigated, although it is estimated in the range of $5-12 \%$ depending on the sample. Only the samples fired at 1100 and $1125^{\circ} \mathrm{C}$ had their properties further investigated due to their superior volumic mass, but also their superior cohesion.

\section{Compressive Strength}

Compressive strength of the samples fired at $1125^{\circ} \mathrm{C}$ greatly exceeded those of samples fired at $1100{ }^{\circ} \mathrm{C}$. Along with superior volumic mass, it revealed that an optimal firing temperature was around $1125^{\circ} \mathrm{C}$. The maximal compressive strength was reached for the 1125-20 sample, with around $65 \mathrm{MPa}$. Compressive strength was then reduced when increasing the clay content, although the 1100-70 and 112570 samples exhibited high compressive strength (even after being fired at $1100^{\circ} \mathrm{C}$ ). The difference between 1100 and 70 and 1125-70 compressive strength was significantly lesser than between 1100 and 20 and 1125-20 samples (Fig. 6). This could be explained by the fact that, clay and MWIBA powders being chemically different, the formed phases during firing might be different (in nature or prevalence), resulting in different properties. Another explanation relates to the fact that the benefit of having such different granulometry for the powders is conditioned by a balance between fines (clay) and coarse (mwiba) particles.

\section{Thermal Properties}

The volumetric specific heat is the product of volumetric mass and specific heat. The samples fired at $1125^{\circ} \mathrm{C}$ exhibit higher densities, but the 1100-70 sample exhibit higher specific heat. However, the highest volumetric specific heat is obtained for 1125-20 sample. It is interesting to notice that the gain in volumetric specific heat between firing at 1100 and $1125^{\circ} \mathrm{C}$ is more important for the $20 \%$ wt clay than for the other formulations (Fig. 7). The fact that this sample shows the higher compressive strength and the second density indicates that its operational conditions enabled satisfying sintering and interparticulate void filling. Thermal conductivity is low for every sample, not one reaching

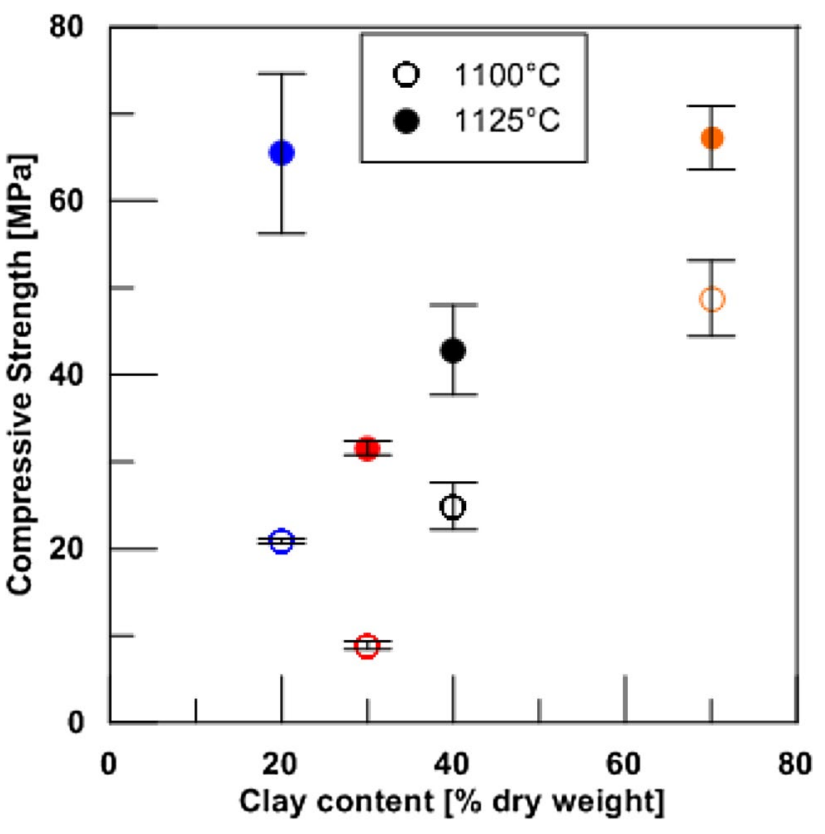

Fig. 6 Compressive strength as a function of clay content, after firing at (open circle) $1100{ }^{\circ} \mathrm{C}$ and (filled circle) $1125^{\circ} \mathrm{C}$

$1 \mathrm{~W} /(\mathrm{mK})$. Again, the samples sintered at $1125{ }^{\circ} \mathrm{C}$ exhibit higher properties than those sintered at $1100{ }^{\circ} \mathrm{C}$. The gain in thermal conductivity is less important the higher the clay content.

Our goal being to use mainly MWIBA to produce the best thermal storage ceramic achievable, we choose to focus on 20 and $30 \%$ clay content formulation, with $1125^{\circ} \mathrm{C}$ firing temperature. These ceramics are required to withstand thermal cycling without mineralogical modifications, and reasonably low thermal expansion, so their behavior when cycled from room temperature to $1000{ }^{\circ} \mathrm{C}$ has been investigated.

\section{Thermal Stability}

This ceramic material is supposed to store and deliver heat over long periods, and will undergo thermal cycling, up to $1000{ }^{\circ} \mathrm{C}$, mostly under air. It should therefore be thermally stable between room temperature and $1000{ }^{\circ} \mathrm{C}$, regarding both mineralogy and thermal expansion. Even if the samples have been fired at temperatures exceeding $1000^{\circ} \mathrm{C}$, it is 


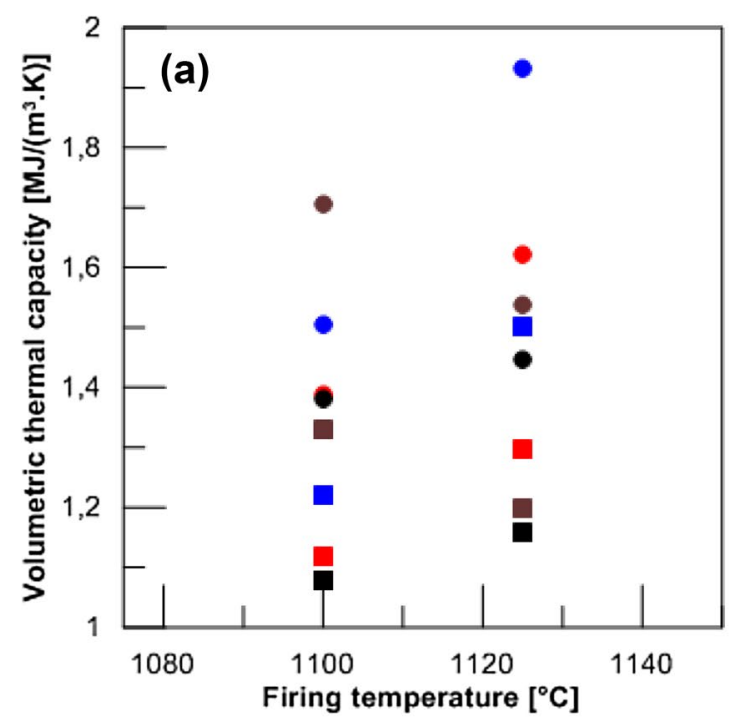

Fig. 7 a Thermal volumetric capacity at room temperature (squares) and $390{ }^{\circ} \mathrm{C}$ (dots), for samples fired at 1100 and $1125^{\circ} \mathrm{C}$, using $20 \%$ (filled blue circle), 30\% (filled red circle), $40 \%$ (filled black circle) and $70 \%$ (filled brown circle) wt clay. b Thermal conductivity at

necessary to verify that there will be no significant changes in structure and properties during use. The best samples (1125-20 and 1125-30) have been thermally cycled three times from 30 to $1000{ }^{\circ} \mathrm{C}$ under air, with $10^{\circ} \mathrm{C} /$ min heating ramp and $30 \mathrm{~min}$ isotherm in a TMA/TG-ATD device (TMA Setsys, from Setaram, TG-ATD Labsys from Setaram), to detect any transformations that might occur. It appears that, even if the heat flow signal varies and present hysteresis between the heating and the cooling phases, the curves are almost identical from one cycle to another, so it is reasonable to conclude that the sample did not undergo significant irreversible transformations (Fig. 8). The clear endothermic behavior can be attributed either to an increase in specific heat, or to a reversible phase change, which did not affect the thermomechanical behavior, thus not introducing concerning weaknesses when the samples are cycled.

The thermal behavior of the samples has been investigated with TMA, to monitor thermal expansion coefficient as a function of temperature. It appeared that 1125-20 and 1125-30 samples exhibited the exact same thermal dilatation coefficient for a given temperature (Fig. 9), reaching a value of $8 \times 10^{-6} / \mathrm{K}$ at $1000{ }^{\circ} \mathrm{C}$, similar to alumina [29]. The endothermic events detected on DTA, if attributed to phase transformation, did not generate disruptions in the variations of CTE.

\section{Mineralogy}

Samples fired at 1100 and $1125^{\circ} \mathrm{C}$, with $20,30,40 \%$ dry weight clay have been characterized in terms of mineral

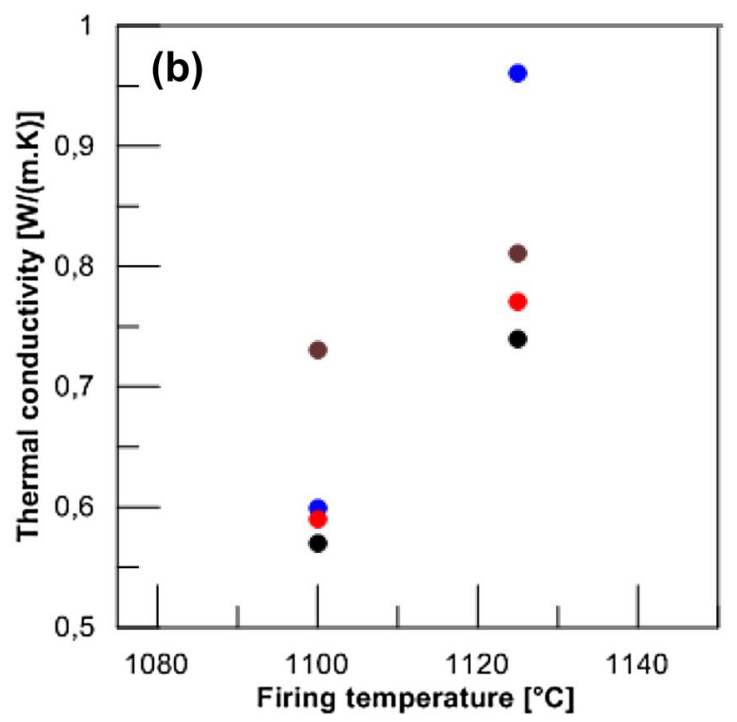

room temperature, for samples fired at 1100 and $1125{ }^{\circ} \mathrm{C}$, using $20 \%$ (filled blue circle), $30 \%$ (filled red circle), $40 \%$ (filled black circle) and $70 \%$ (filled brown circle) wt clay. (Color figure online)

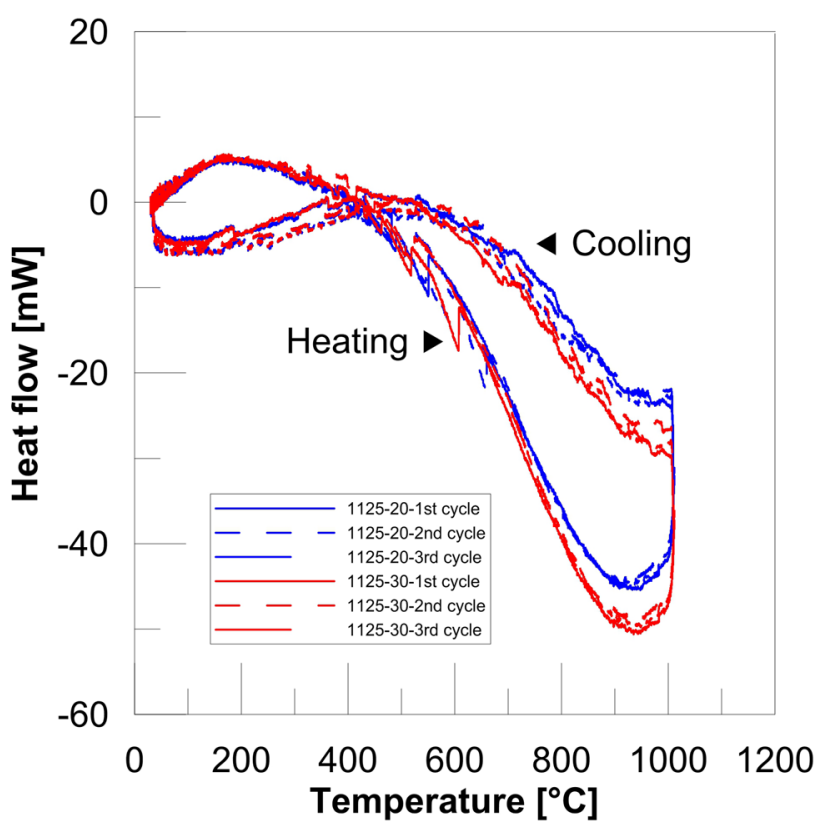

Fig. 8 DTA for 1125-20 and 1125-30 samples, cycled three times from room temperature to $1000^{\circ} \mathrm{C}$

composition (Fig. 10). Overall, all samples exihibited the presence of the same mineral phases, namely Quartz, Clinoenstatite, Wollastonite and Albite. No new phases appeared depending on the clay ratio nor the firing temperature. Some samples exhibited low-level noise under $20^{\circ}$, typical linked to glassy phases. 


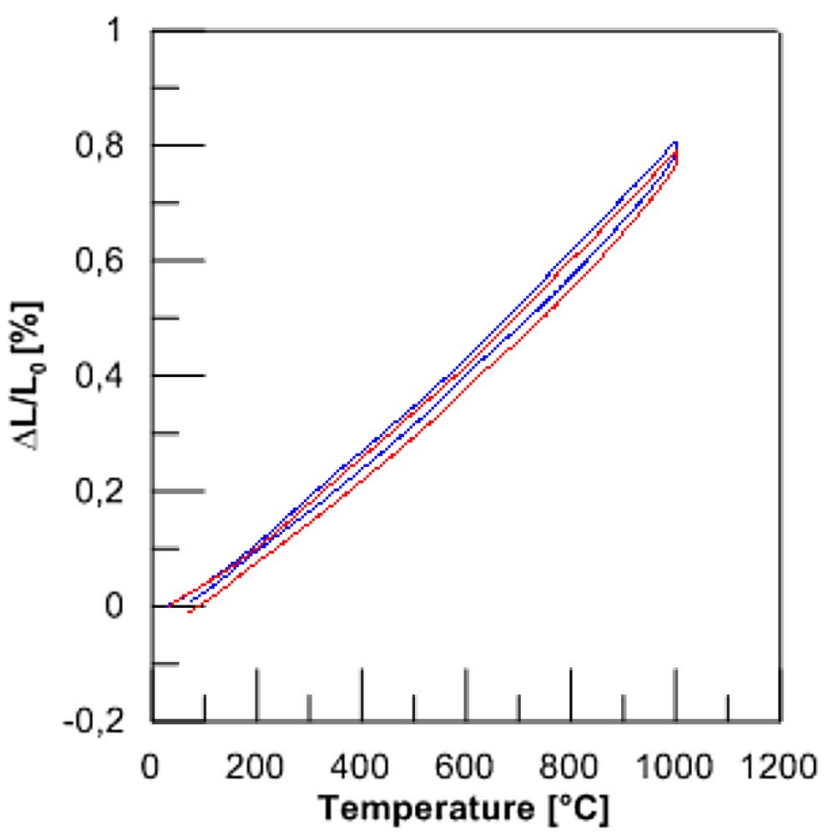

Fig. 9 Thermal expansion as a function of temperature, for 1125-20 (filled blue circle) and 1125-30 (filled red circle) samples. (Color figure online)

The XRD patterns of the samples reveal some interesting points:

- After firing at $1100{ }^{\circ} \mathrm{C}$, the same mineral phases have been detected, with 20,30 and $40 \%$ wt clay samples, namely quartz, wollastonite, clinoenstatite and albite.
However, increasing the clay content seems to increase the signal for albite (perhaps favored by the higher alumina content of the clay) and quartz, while decreasing it seems to favor wollastonite (perhaps favored by the higher calcium content of MWIBA) and clinoenstatite (favored by the presence of magnesia, which is not contained into the clay). The behavior of $\mathrm{MgO}$ during firing might need further investigation because, although being present at low concentrations in MWIBA, MgOcontained mineral phases are ubiquitous in works regarding MWIBA, be it clinoenstatite (in the present work) or diopside $[11,27,30]$.

- After firing at $1125^{\circ} \mathrm{C}$, the peaks on the XRD pattern are similar. No new phase appeared, although the peaks are slightly narrower, which could indicate better crystallization. The fact that the low-level noise at low angles is lower for the samples fired at $1125^{\circ} \mathrm{C}$ could imply better crystallization as well. The superior properties of the $1125^{\circ} \mathrm{C}$ samples are therefore not related to the crystallization of new phases, but to crystal growth, densification and relative proportions of the different mineral phases. The fact that albite melts in these temperature ranges $\left(1100-1120^{\circ} \mathrm{C}\right)[31]$ can explain the higher density of samples sintered at $1125^{\circ} \mathrm{C}$, the resulting viscous phase allowing viscous flow sintering. However, the fact that Albite can show high thermal expansion with increasing temperature [31] could be partly responsible for the formation of closed porosity in the bulk.
Fig. 10 a XRD patterns of samples sintered at $1100^{\circ} \mathrm{C}$. (open circle) Quartz, (filled square) Wollastonite, (open triangle) Clinoenstatite, (filled inverted triangle) Albite, b XRD patterns of samples sintered at $1125^{\circ} \mathrm{C}$. (open circle) Quartz, (filled square) Wollastonite, (open triangle) Clinoenstatite, (filled inverted triangle) Albite
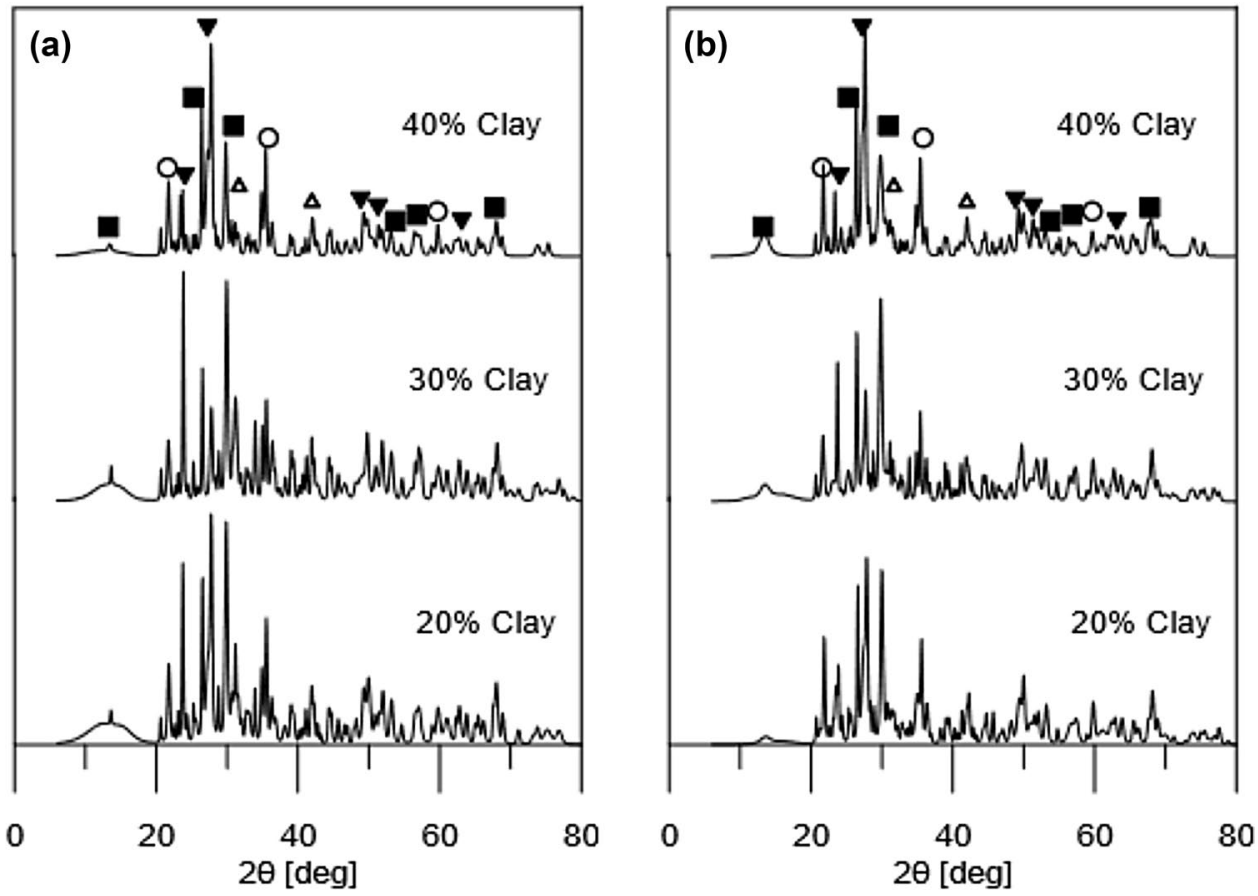


\section{Conclusions}

Municipal Waste Incinerator Bottom Ashes have been milled and mixed with various amounts of a wasted illictic clay, to explore the technical feasibility of ceramic sintering, to be used for thermal energy storage material production.

The trials revealed the feasibility of pressed plates production, using only widely available production techniques. The samples fired at $1125^{\circ} \mathrm{C}$ exhibited the best properties, whether on the mechanical or thermal characteristics, the samples containing 20, 40 and 70\% wt clay reaching over $40 \mathrm{MPa}$ for compressive strength, as well as exhibiting the highests thermal volumetric storage capacity. XRD analysis revealed that all samples fired at 1100 and $1125^{\circ} \mathrm{C}$ contained the same mineral phases, the variations of properties could therefore be explained by variations of the relative proportions of those mineral phases, and quality of sintering (especially regarding porosity filling during firing).

The samples have been cycled thermally between room temperature and $1000{ }^{\circ} \mathrm{C}$, and did not exhibit significant modification of their properties, allowing considering them reasonably stables.

However, the visible high level of closed porosity of the samples limits the volumetric heat capacity, and should therefore be addressed to increase their potential as thermal energy storage materials.

- Decreasing the particle size of MWIBA powder could be interesting, as it would allow higher specific surface of the powder, thus favor grain-bounding during firing.

- Replacing the clay by another one exhibiting lower densification temperature could be an option, as in our case the MWIBA starts melting long before the maximum clay densification.

- An optimization of powders granulometries prior to mixing could be relevant, using a Funk strategy. This consists in mixing powders with different particle size distribution, to reach an uniform repartition of particle size in a broad particle size range. This approach, currently used for concrete production [32] as well as refractory cement production [33] could greatly improve green bodies compacity, favoring densification and reducing bulk porosity after firing (as well as linear shrinkage).

Although this work focused on the development of a thermal energy storage ceramic to be used in thermocline storage system, the high compressive strength, associated with limited thermal conductivity and average volumic mass could be compatible with the requirements for building purposes. Regarding these applications however, more work would be required to limit shrinkage and creeping during firing operations, as well as investigating water absorption, frost resistance and pollutant leaching behavior over time.

Acknowledgements This work was supported by the Programme "Investissements d'avenir" (Investment for the Future) of the Agence Nationale de la Recherche (National Agency for Research) of the French State under award number ANR-10-LABX-22-01-SOLSTICE. The author would also like to thank Eco-Tech Ceram for their scientific, material and financial support and the SPCTS CNRS UMR 7315 for their support.

\section{References}

1. International Solid Waste Association.: Management of Bottom Ash from WTE Plants-An Overview of Management Options and Treatment Methods, International Solid Waste Association, Vienna (2006)

2. AMORCE.: Etat des lieux de la gestion des mâchefers en France. AMORCE, Villeurbanne Cedex, (2012)

3. Ministère de l'environnement.: Chiffres clés des énergies renouvelables - Édition 2016, Ministère de l'environnement, Paris (2017)

4. International Solid Waste Association.: Waste-to-Energy Stateof-the-Art-Report. International Solid Waste Association, Vienna (2012)

5. Vu, D.H., Wang, K.-S., Chen, J.-H., Nam, B.X., Bac, B.H.: Glass-ceramic from mixtures of bottom ash and fly ash. Waste Manag. 32, 2306-2314 (2012). https://doi.org/10.1016/j.wasma n.2012.05.040

6. Bethanis, S., Cheeseman, C.R., Sollars, C.J.: Properties and microstructure of sintered incinerator bottom ash. Ceram. Int. 28, 881-886 (2002). https://doi.org/10.1016/S0272-8842(02)00068-8

7. Barbieri, L., Karamanov, A., Corradi, A., Lancellotti, I., Pelino, M., Rincon, J.M.: Structure, chemical durability and crystallization behavior of incinerator-based glassy systems. J. Non. Cryst. Solids. 354, 521-528. (2008) https://doi.org/10.1016/j. jnoncrysol.2007.07.080

8. Schabbach, L.M., Andreola, F., Karamanova, E., Lancellotti, I., Karamanov, A., Barbieri, L.: Integrated approach to establish the sinter-crystallization ability of glasses from secondary raw material. J. Non. Cryst. Solids. 357, 10-17 (2011). https://doi. org/10.1016/j.jnoncrysol.2010.10.006

9. Aloisi, M., Karamanov, A., Taglieri, G., Ferrante, F., Pelino, M.: Sintered glass ceramic composites from vitrified municipal solid waste bottom ashes. J. Hazard. Mater. 137, 138-143 (2006). https://doi.org/10.1016/j.jhazmat.2005.12.056

10. Appendino, P., Ferraris, M., Matekovits, I., Salvo, M.: Production of glass-ceramic bodies from the bottom ashes of municipal solid waste incinerators. J. Eur. Ceram. Soc. 24, 803-810 (2004). https://doi.org/10.1016/S0955-2219(03)00264-4

11. Bourtsalas, A, Vandeperre, L.J., Grimes, S.M., Themelis, N., Cheeseman, C.R.: Production of pyroxene ceramics from the fine fraction of incinerator bottom ash. Waste Manag. 45, 217225 (2014). https://doi.org/10.1016/j.wasman.2015.02.016

12. Barbieri, L., Corradi, A., Lancellotti, I.: Bulk and sintered glassceramics by recycling municipal incinerator bottom ash. J. Eur. Ceram. Soc. 20, 1637-1643 (2000). https://doi.org/10.1016/ S0955-2219(00)00032-7 
13. Sétra.: Acceptabilité environnementale de matériaux alternatifs en technique routière - Les mâchefers d'incinération de déchets non dangereux (MIDND). Sétra, Boxborough (2012)

14. Rambaldi, E., Esposito, L., Andreola, F., Barbieri, L., Lancellotti, I., Vassura, I.: The recycling of MSWI bottom ash in silicate based ceramic. Ceram. Int. 36, 2469-2476 (2010). https://doi. org/10.1016/j.ceramint.2010.08.005

15. Lopez Ferber, N., Falcoz, Q., Minh, D.P., Hoffmann, J.F., Meffre, A., Nzihou, A., et al.: Flexibility and robustness of a hightemperature air / ceramic thermocline heat storage pilot. J. Energy Storage. 21, 393-404 (2019). https://doi.org/10.1016/j. est.2018.11.034

16. Zanganeh, G.: High-temperature thermal energy storage for concentrated solar power with air as heat transfer fluid, ETH Zurich (2014). https://doi.org/10.3929/ETHZ-B-000225616

17. Py, X., Calvet, N., Olives, R., Meffre, A., Echegut, P., Bessada, C., et al.: Recycled material for sensible heat based thermal energy storage to be used in concentrated solar thermal power plants. J. Sol. Energy Eng. 133, 031008 (2011). https://doi. org/10.1115/1.4004267

18. Dejean, G.: Valorisation de laitiers sidérurgiques comme matériaux de stockage thermique pour procédés énergétiques durables. Application au CSP et au CAES, UPVD, Perpignan (2014)

19. Kere, A., Sadiki, N., Py, X., Goetz, V.: Applicability of thermal energy storage recycled ceramics to high temperature and compressed air operating conditions. Energy Convers. Manag. 88, 113-119 (2014). https://doi.org/10.1016/j.enconman.2014.08.008

20. European Commission.: Document de référence sur les meilleures techniques disponibles - Fabrication des céramiques. European Commission, Brussels (2007)

21. Taurino, R., Karamanova, E., Barbieri, L., Atanasova-vladimirova, S., Andreola, F., Karamanov, A.: New fired bricks based on municipal solid waste incinerator bottom ash. Waste Manag. Res. 35, 1055-1063 (2017). https://doi.org/10.1177/0734242X1772134 3

22. Zavattoni, S.A.A., Barbato, M.C.C., Pedretti, A., Zanganeh, G., Steinfeld, A.: High temperature rock-bed TES system suitable for industrial-scale CSP plant-CFD analysis under charge/discharge cyclic conditions. Energy Procedia. 46, 124-133 (2014). https:// doi.org/10.1016/j.egypro.2014.01.165

23. IUPAC.: Compendium of Chemical Terminology—Gold Book. IUPAC, Research Triangle Park, (2014)
24. Becquart, F., Bernard, F., Abriak, N.E., Zentar, R.: Monotonic aspects of the mechanical behaviour of bottom ash from municipal solid waste incineration and its potential use for road construction. Waste Manag. 29, 1320-1329 (2009). https://doi.org/10.1016/j. wasman.2008.08.019

25. Florida State University, Archimedes' Principle. Florida State University, Tallahassee (2014)

26. Rahaman, M.N.: Ceramic Processing, second edition, CRC Press, Boca Raton 2017

27. Cheeseman, C.R., Monteiro Da Rocha, S., Sollars, C., Bethanis, S., Boccaccini, A.R.: Ceramic processing of incinerator bottom ash. Waste Manag. 23, 907-916 (2003). https://doi.org/10.1016/ S0956-053X(03)00039-4

28. Schabbach, L.M., Andreola, F., Barbieri, L., Lancellotti, I., Karamanova, E., Ranguelov, B., et al.: Post-treated incinerator bottom ash as alternative raw material for ceramic manufacturing. J. Eur. Ceram. Soc. 32, 2843-2852 (2012). https://doi.org/10.1016/j.jeurc eramsoc.2012.01.020

29. Auerkari, P.: Mechanical and physical properties of engineering alumina ceramics. Tech. Res. Cent. Finl. 1792, 26 (1996)

30. Qian, G., Song, Y., Zhang, C., Xia, Y., Zhang, H., Chui, P.: Diopside-based glass-ceramics from MSW fly ash and bottom ash. Waste Manag. 26, 1462-1467 (2006). https://doi.org/10.1016/j. wasman.2005.12.009

31. Anovitz, L.M., Blencoe, J.G.: Dry melting of high albite. Am. Mineral. 84, 1830-1842 (1999). https://doi.org/10.2138/ am-1999-11-1210

32. Radix, H.J., Brouwers, H.J.H.: Self-Compacting concrete: the role of the particle size distribution. In: International Symposium for High-Performance. Use Self-Consolidating Concrete, Changsha, Hunan, China, pp. 26-28 (2005). https://doi.org/10.1617/29121 43624.01

33. Kalpakli, Y.K.: Effects of particle size distribution on the refractory properties and corrosion mechanism of ultra-low cement castables. Arch. Mater. Sci. Eng. 34, 81-88 (2008) 